\title{
Asturian Language
}

National Cancer Institute

\section{Source}

National Cancer Institute. Asturian Language. NCI Thesaurus. Code C153841.

A West Iberian Romance language spoken in the Principality of Asturias, Spain. 